\title{
Ecotourism in Nepal
}

\author{
Anup K. C.*
}

\begin{abstract}
Ecotourism gives priority to ecological resource integrity, environmental conservation, community development and economic development by maintaining low-impact and non-consumptive use of local resources. There are different forms of ecotourism developed worldwide as communitybased ecotourism, ecosystem ecotourism, cultural ecotourism, nature based ecosystem, protected area ecotourism and rural ecotourism. It focuses on meeting three concurrent goals of biodiversity conservation, poverty reduction and business viability using sustainable principles and practices. In sustainable ecotourism, local government officials, local communities, NGOs, private sector and management committee had a great role for tourism development and maintaining healthy cooperation and coordination. Ecotourism had more beneficial impacts compared to adverse impacts on the environment, society and culture. It emphasizes the protection of natural resources, biological diversity and sustainability of resource. It increases mobility of people, social stability and harmony; strengthen traditional culture, hospitality and folkway; and decreases political conflicts. Economic benefits from ecotourism include direct employment in hotels, lodges, tourist restaurants, and tourist chauffeuring. It is an integral part of the master development strategy of a developing nation. In Nepal, ecotourism helps to enhance forest cover, flora, fauna, greenery, alternative energy sources, natural resource, biodiversity and other environmental benefits. It had helped in controlling antisocial activities, conserving religious and cultural heritage, maintaining peace and prosperity and increase in cooperation of people with religious beliefs and religious tolerance. It had a great role in poverty alleviation, rural development, agricultural transformation, community enrichment and social empowerment of women in Nepal. In the early stage of ecotourism development, it is difficult to have adequate private agencies and local people involved in delivering lodging, fooding, tour management and tourism activities during peak visitation season.
\end{abstract}

\footnotetext{
* Anup K.C. is an eminent scholar who has already published several research articles on tourism, climate change, ecology and environment in International Journals. Currently he is working at Nepal Electricity Authority, Environment and Social Studies Department, Kharipati, Bhaktapur, Nepal. Email:kcanup04@gmail.com
} 
There is need of training on nature guiding, cooking, sustainable use of tourism resources, proper handling of tourism demands, expertise in park management and finance management.

Keywords: Ecotourism, Environmental Impacts, Social Impacts, Economic Impacts, Nepal

\section{Introduction of Ecotourism}

Ecotourism is one of the important branches of the sustainable tourism industry which focuses on biodiversity conservation, environmental protection, poverty alleviation and economic development (Duffy, 2008; K. C., 2016; K.C., Rijal, \& Sapkota, 2015). Among the different types of tourism industry, ecotourism protects and conserves natural resources by providing employment to the people (K.C. \& Thapa Parajuli, 2014b). It gives priority to ecological resource integrity, environmental conservation, community development and economic development by maintaining low-impact and non-consumptive use of local resources (Stem, Lassoie, Lee, \& Deshler, 2003). There is need of accessibility, liberalization, community empowerment, tourism facilities, tourism products, basic accommodation and public participation (Duffy, 2008; Gurung \& Scholz, 2008).

Different experts and organizations have different views on ecotourism. It is also differing according to the location, special characteristics of the region, and facilities of ecotourism and nature of activities offered by ecotourism entrepreneurs. Winter sports tourism in snowy mountain is important component of local and national tax revenue in some countries, trekking and mountaineering tourism is important in other mountainous countries, recreational activities near the sea is important in the countries connected with oceans, cultural tours and visit is famous in cultural heritage rich countries and site visit is important in naturally and ecologically rich countries. Tourism can be promoted in artificially and naturally developed area while ecotourism is more successful in naturally developed areas.

Ecosystem ecotourism integrates sustainable development with ecosystem structures and functions by managing biological diversity in relation to tourism experience for absorbing or adapting the pressures of tourists (Tyler \& Dangerfield, 1999). Rural ecotourism takes place in rural environment with rural resources showing rurality, traditional culture, agricultural sightseeing, farming experience and rural accommodations and entertainment (Degang \& Xiaoting, 2006). Cultural ecotourism focuses on cultural traditions, life of local communities, minority cultures and cultural traditions (Genzong, Penghua, \& Shaoxia, 2007). Nature-based ecotourism focuses on natural resources in parks and protected areas and environment quality (Eagles, 2002).

Ecotourism is an alternative form of tourism which enhances tourism in the biophysical environment and supports ecologically sustainable activities, 
conservation supporting measures and involvement of local communities (Dowling, 2000; K. C., 2016). It also focuses on community development, poverty alleviation, wildlife conservation, environmental protection and traditional economic bases like agriculture, livestock and hunting (Duffy, 2008). It supports job, market, culture, ownership, management, coordination, wildlife conservation and equitable sharing of benefits in the local area (Sindiga, 1999). Sustainable principles and practices are supported by fulfilling goals of biodiversity conservation and poverty reduction; and by maintaining national standards of atmospheric quality, sound quality, drinking water and sewage (Degang \& Xiaoting, 2006; Hawkins, 2004).

Ecotourism focuses on responsible travel to natural areas by conserving environment, improving well-being of local people, travelling to natural areas, minimizing impact, building environmental awareness, and providing direct financial benefits, empowerment for local people and respects to their local culture (Honey, 2008). It prioritizes tourism industry with sustainable development goals of conserving nature, benefiting local people and educating tourists towards sustainability. Government, nongovernmental organizations, local communities and businessman should be involved to manage tourist with proper guideline, certification and regulations. It creates innovative activities to attract visitors, provide opportunity to interact with nature and helps to conserve flora and fauna (Wood, 2002).

Responsible ecotourism include those activities to minimize the negative aspects of conventional tourism on the environment and enhance the cultural integrity of local people. In addition to evaluating environmental and cultural factors, ecotourism involves promotion of recycling, energy efficiency, water conservation, and creation of economic opportunities for local communities (Randall, 1987). According to Ceballos Lascurain (1996), "Ecotourism is defined as travelling to relatively undisturbed natural areas with specific objective of studying, admiring and enjoying scenery and its wild animals and plants as well as existing cultural assets found in these areas".

Ecotourism is environmentally responsible travel and visit to undisturbed natural areas for enjoyment and appreciation of nature that promotes conservation with low visitors impacts and active socio-economic involvement of local population (Ceballos-Lascurain, 1996). It supports biodiversity conservation, local development, job employment, market for local products and encourages cultural sensitivity in guest-host relations. Direct benefit sharing and planning is minimal to integrate national tourism objectives with local needs to landowners. It is taken as a catalyst for encouraging ecologically sustainable development with a harmonious relationship with nature, local communities, their cultures and customs (Sindiga, 1999). Ecotourism contribute greatly towards Gross Domestic Product (GDP) for developing countries like Nepal which are rich in natural environment and culture (Amati, 2013; UNEP, 2013). 


\section{Principle of Ecotourism}

Ecotourism focuses on meeting three concurrent goals using sustainable principles and practices: (1) biodiversity conservation through protection of natural and cultural resources; (2) poverty reduction through small and medium size enterprise development, job creation, and social equity measures; and (3) business viability through access to capital, return on investment and profitability. Growing environmental awareness and advances in transportation and communication has made ecotourism one of the fastest-growing segments in the travel industry. Equity investments and financial facilities are essential for the development of ecotourismrelated businesses in protected areas. Strategic planning, financial analysis, technical assistance and business plan development are also needed to create entrepreneurialdriven sustainable development and to improve the quality and viability of ecotourism (Hawkins, 2004).

The principle of ecotourism minimizes impacts of tourism, builds environmental and cultural awareness and provides positive experiences to visitors and hosts. It provides direct financial benefits for conservation and helps in upliftment of society. It raises sensitivity of the host country's political, environmental and social issues and supports international human rights and labor agreements (TIES, 1990). Ecotourism involves education and interpretation of natural environment to manage it in an ecologically sustainable way. It is labor intensive and offers a variety of small scale opportunities creating jobs for poor, women, and young people, and jobs for indigenous community. It takes care of natural resources and helps to earn money through tourism enterprise to better their lives. It involves conservation, business enterprise and community development with the help of direct and indirect participants and beneficiaries (Das \& Syiemlieh, 2009).

Ecotourism creates sustainable economic development through conservation objectives and balances the conflicting goals of economic development and biodiversity conservation. It is the sector of the larger tourism industry focusing on bringing benefits to local communities and protecting natural areas. Development of ecotourism makes biodiversity conservation economically viable for local communities. Additional sources of income from ecotourism come from sale of traditional handicrafts and agricultural products. National and international level coordination is important for the sustainability of ecotourism projects. Multiple government departments, including ministries of tourism, natural resources and rural development coordinates policies and programs to pursue the success of ecotourism projects. International organizations which provide support to ecotourism projects should coordinate with government agencies and local non-profits (Cusack \& Dixon, 2006). 
Ecotourism is one of the preferred tools for conservation and community development in rural areas. It depends on the potential to provide local economic benefits by maintaining ecological resource integrity through low-impact and nonconsumptive use of local resources. Successful ecotourism initiatives get higher number of tourists and they solve problems of solid waste generation, habitat disturbance, and trail erosion. Such impacts could seriously threaten the resources upon which ecotourism depends. Ecotourism provides local economic benefits by maintaining ecological resource integrity through low-impact and non-consumptive resource use. It financially supports protected areas through tourism-related park fees (Stem, et al., 2003).

\section{Different Forms of Ecotourism}

There are different forms of ecotourism named according to the nature, context and practices of ecotourism. They are named differently according to the types, place and characteristics of ecotourism followed in the particular region.

\section{Community Based Ecotourism}

Local income, biodiversity conservation and cultural preservation are necessary for community based ecotourism (CBE) promotion in remote areas. Successful implementation of $\mathrm{CBE}$ project requires improvement of accessibility, liberalization of pricing policy, community empowerment, and development of tourism facilities and incorporation of nature-based tourism products. To increase social, economic and environmental benefits, tourism development in protected areas should focus on interdisciplinary and interdepartmental effort with collaboration between the conservation and tourism authorities (Gurung \& Scholz, 2008).

Ecological sustainability and local community development is focused in community-based ecotourism. Environmental sensitivity and responsibility promoted by ecotourism provide political, economic and social benefit to host communities. Community-based ecotourism requires local employment and benefits through local initiation and control. It enhances social status, mobility, social cohesion, harmony and ecological sustainability. Environmental sensitivity and responsibility promoted by ecotourism can serve political, economic, social and environmental interests of host communities. The relationship between community based ecotourism and empowerment is complex and incomplete, and the economic and psychological empowerment of individuals is attained by political and social empowerment of communities (Kontogeorgopoulos, 2005).

Ecotourism offers both the service and experience. Historic places and parks provide emotional experience and psychological benefits to ecotourist (Chan \& Baum, 2007). It supplies real experiences of natural environment and the whole ecosystem (Tyler \& Dangerfield, 1999). Ecotourism experiences include seeing 
wildlife in its natural habitat and preservation of natural environment, enjoying basic accommodation and facilities and acquiring knowledge about nature and the environment (Chan \& Baum, 2007). The attractive and beautiful scenery of snowy mountains, green hills, lakes, rivers and forest makes the ecotourist feels like the real experience of heaven. The melodious sound of bird, insects and wild animals in the wilderness area provides spiritual sensation to every people.

\section{Ecosystem Ecotourism}

Ecosystem includes living organisms, physical environment and their interactions and feedbacks. The herbivory, predation, parasitism and mutualism between biotic and abiotic components provide basic components in ecosystem tourism. Ecosystem tourism is supply led tourism strategy with the central theme of ecosystem integrity enabling sustainable development. It does not exclude tourist and commercial exploitation of the ecosystem. It depends on integrated management philosophy considering beneficiaries, socioeconomic constraints and impacts on the resource base within a realistic spatial and temporal scale. It requires entire ecosystems or the biological diversity managed in relation to the tourism experience. (Tyler \& Dangerfield, 1999). In this type of ecotourism, activities are focused in such a way that helps to maintain the structures and functions of ecosystem.

\section{Rural Ecotourism}

Rural ecotourism promotes the combination between agriculture and tourism, enhances the profits from agriculture and provides peasantry with more profit, more employment opportunities and better living conditions. It plays a positive role in prompting the development of rural economy and rural culture through agricultural sightseeing and experience with traditional accommodations and simple entertainment. Rural tourism was originated in Europe to develop tourism in a sustainable way with rural environment, rural reflections, and agricultural products as a source of tourist attractions, peasantry life style and traditional folk custom. It takes place in rural environment based on the available resources of rural scenario. In rural tourism, tourists enjoy staying in the yard, strolling and looking around flowers, green plants, gardens, old architecture and by playing cards or mahjong. There are few packing houses, butchers and packmen, distance carriers and souvenir shop which provide service to the tourist in the form of chefs, waiters and office boys. It generates second revenue for the local villagers with the help of traditional hospitality, honest folkway and environmental conservation. Atmospheric quality, sound quality, drinking water, sewage, lampblack and all kinds of resources meet the national standards of environmental conservation (Degang \& Xiaoting, 2006). 


\section{Sustainable Ecotourism}

In sustainable ecotourism, local government officials, local communities, NGOs, private sector and management committee had a great role for conservation, development and logistical functions towards tourism development and maintaining healthy cooperation and coordination. Local governments should develop fund from provincial and national governments or NGOs for preparation of management plan and proper functioning of nature reserve with the support of management committee. There is need of control of air pollution, wastewater and waste management; develop and implement wildlife conservation policies; and focus on conservation and education programs. Also, scientific researches, monitoring programs and environmental impact assessments should be conducted for conserving biodiversity and enhance tourism and other human activities that have negative impact on the wildlife and their habitat. Research opportunities should be provided to attract scientists and students to conduct research in the region. Sustainable forestry projects should be developed to maximize potential production and maintain the natural diversity, structure and function of the forest ecosystems (Genzong, et al., 2007).

Sustainable ecotourism imposes less environmental impacts, minimizes negative externalities, promotes environmental and cultural integrity, and helps in effective resource management and generation of income (UNEP, 2013). Developing countries have advantage from ecotourism as they have unique natural environments, cultures and opportunities for adventure holidays. It generates employment for the unskilled workforce in rural area through community-led tourism activities for preserving natural ecosystems (UNEP, 2013). For ecotourism programme to be sustainable, all the environmental, social and economic aspects should be taken care off. Economic activities should be focused by conserving the nature, culture and moral aspects of the society. Local resources, local traditions and local manpower should be prioritized for attaining sustainability in ecotourism.

\section{Cultural Ecotourism}

It is an important aspect of ecotourism where there is need of preservation of cultural traditions to enrich the quality of the life of local communities. It is necessary to develop and promote minority cultures to preserve cultural traditions and organize education and training programs of ecotourism and nature reserve to tourism operators, employees and tourist (Genzong, et al., 2007). Cultural ecotourism is one of the most popular forms of ecotourism developed worldwide from the historical past. Religious places, cultural monuments, historical buildings, traditional museums and popular arts and sculptures are the main bases of cultural ecotourism. Religious beliefs, dresses, languages, music, literatures, occasions, festivals and traditions are the main source of attractions and entertainment for ecotourists. 


\section{Impacts of Ecotourism}

Ecotourism had both beneficial and adverse impacts on the environment, society and culture. In comparison, there are more beneficial impacts and few adverse impacts on different components of environment.

Environmental Impacts

Ecotourism emphasizes the protection of natural resources, biological diversity and sustainability of resource (Bin, Suocheng, \& Mei, 2008). It is a supply led tourism strategy that does not exclude the tourist and commercial exploitation of the ecosystem. It enables sustainable development with the central theme of ecosystem integrity and encourages local people for the conservation and protection of the environment (Degang \& Xiaoting, 2006; Tyler \& Dangerfield, 1999). It generates community benefits from conservation and protection of the environment and biodiversity (Ormsby \& Mannle, 2006). Forest area, natural resources and biological diversity can be increased while sustainability of resource use and tourism resources can be enhanced during tourism development (Bin, et al., 2008).

Ecotourism influences conservation, decreases deforestation and hunting rate and discourages conversion of forest to agricultural and pastoral land (Stem, et al., 2003). It is one of the preferred tools for conservation and community development that increases benefit of communities and conservation activities (Duffy, 2008). In ecotourism, natural resources are protected by increasing recreational and tourist potential as a center of attraction (Kelkit, Ozel, \& Demirel, 2005). It enriches the area with natural regeneration, new plantations, infrastructural development and new destination for visitors and nature-based tourism (Nath \& Alauddin, 2006). There is positive benefit to flora and fauna due to the decrease in environmental and cultural impacts (Brunet, Bauer, De Lacy, \& Tshering, 2001; Winson, 2006).

Ecological sustainability, grassroots development, environmental sensitivity and responsibility promoted by ecotourism can serve the political, economic, social and environmental interests of host communities (Kontogeorgopoulos, 2005). Ecotourism supplies real experiences of natural environments and solution to increased tourists and increased degradation of natural areas (Lieberknecht \& Papazian, 1999). Multisector planning and environment-friendly characteristic of ecotourism brings ecological and economic benefits to community and the whole country (Bin, et al., 2008; Gezon, 2014).

\section{Social Impacts}

Similar to environmental impacts, adverse social impacts are minimal with more positive impacts (Boxill \& Severin, 2004). Ecotourism increases mobility of people, social stability and harmony; strengthen traditional culture, hospitality 
and folkway; and decreases political conflicts (Bin, et al., 2008; Degang \& Xiaoting, 2006; Schellhorn, 2010; Sreekumar \& Parayil, 2002). Ecotourism operators organize cultural tours with different community groups and introduce rich culture to ensure experience of tourism stakeholders (Kelkit, et al., 2005; Stem, et al., 2003). Ecotourism offers diverse products and services categorized as both a service and an experience (Chan \& Baum, 2007). Ecotourism can cause social conflicts between the locals and government authorities and also challenge cultural values due to western influence (Gurung \& Scholz, 2008; Maikhuri, Rana, Rao, Nautiyal, \& Saxena, 2000). There may be increase in alcoholism, drug addiction and prostitution due to tourism (Zambrano, Broadbent, \& Durham, 2010). Foreign cultures brought by tourists have an impact on local tradition and plain cultures (Bin, et al., 2008).

\section{Economic Impacts}

Economic benefits from ecotourism include direct employment in hotels, lodges, tourist restaurants, and tourist chauffeuring. It is an integral part of the master development strategy of a developing nation (Doan, 2000; Stem, et al., 2003). It is important to integrate ecotourism with farming activities, handicraft and other local businesses to bring more benefits in the society (Degang \& Xiaoting, 2006). Parks and protected areas need effective participation of people for resource management and self-reliant communities have greater chance of progress. Local community can play a great role in empowering people to mobilize their own capacities (Singh \& Singh, 2004).

Ecotourism helps to collect revenue from fee and license from parks and overcome the cost of production and coordinate with corporate and non-profit entities (Eagles, 2002; Stem, et al., 2003). Ecotourism is taken as the driving force of socioeconomic development, change in traditional growth patterns and construction of harmonious and environment-friendly society (Eagles, 2002; Sreekumar \& Parayil, 2002). It increases employment, releases environmental pressure and helps in regional economic development. It can attract funds, increase revenue, enhances transportation, improves accommodation, solves poverty problem and enhances social stability and harmony. It transfer rural surplus labors to non-agricultural industries, change the traditional rural lifestyle and productive style, increase the income of farmers and improve the welfare. Ecotourism brings more economic benefits and ecological benefits to the people (Bin, et al., 2008).

\section{Ecotourism in Nepal}

Nepal has an area of 147,181 sq. $\mathrm{km}$. with great diversity of topographic, ecoclimatic, natural and cultural features. It is rich in Himalayan ranges, natural beauty, protected areas, biodiversity, landscape, cultural heritage and ethnic diversity (Bhusal, 2007). It is one of the most adventurous cultural and ecotourism destinations in the 
world with many trekking routes and sites for ecotourists to explore natural beauty from east to west and north to south (K. C., 2016; K.C., et al., 2015; Musa, Hall, \& Higham, 2004; Nepal, 1997). It is naturally and culturally rich with Himalayas, green forests, spring, waterfall, meandering river, lake, fertile valleys, and diverse flora and fauna (Bajracharya et al., 2011).

It is one of the most important adventurous, cultural and ecotourism destinations in the world due to the presence of Himalayas, and cultural and natural attractions. Eight of the 14 mountains in the world over $8000 \mathrm{~m}$ are in Nepal, including the world's highest, Mt. Everest (Musa, et al., 2004). There are fragile, pristine and undisturbed natural areas focusing on low-impact small scale tourism, ecological conservation, economic development and political empowerment of local communities, cultures and human rights (Bajracharya, et al., 2011). Ecotourism in Nepal is based on promoting people participation in planning and management of tourism; increasing community development, nature conservation and tourism linkages; and mobilizing tourism incomes to safeguard resources.

Nepal has a total population of over 27.58 million (CBS, 2014), and it consists of 59 ethnic groups with 101 spoken languages. It is the birthplace of Lord Buddha, the Light of Asia and has more than 1250 heritage sites identified and documented from 72 districts. Kathmandu Development Committee has listed a total of 870 religious and cultural monuments in Kathmandu valley. There are eight World Cultural Heritage Sites: Bhaktapur, Patan and Kathmandu Durbar Squares; Swayambhunath; Baudhanath; Pashupatinath; Changunarayan and Lumbini (the birth place of Lord Buddha) combined with two world's Natural Heritage Sites: Sagarmatha and Chitwan National Parks (Bhusal, 2007; K.C., 2016).

Community-based tourism in protected areas and outside protected areas in different region of Nepal had supported livelihood of local communities (Acharya \& Halpenny, 2013; Nepal, 1997). As a result, Government of Nepal has developed protected areas and cultural heritage sites for conserving wildlife, preserving culture and enhancing ecotourism (Baral, Stern, \& Hammett, 2012). In such areas, tourists enjoy seeing mountain ranges, natural beauty, protected biodiversity, landscape, cultural heritage and ethnic diversity (Bhusal, 2007; K. C., 2016). Tourism had already been an alternative source of income generation in many rural and cultural villages of Nepal through rural tourism initiatives (Acharya \& Halpenny, 2013; K.C., et al., 2015).

In Sagarmatha National Park (SNP) (one of the natural heritage site), tourist can enjoy scenic beauty, trek and climb Mountains, view Mt. Everest, enjoy local cultures and traditions, and enjoy wilderness. There is inclusion of local participation, economic viability, education dissemination, tourist satisfaction and tourism impact 
reduction for sustaining ecotourism (Musa, et al., 2004). Climate change, unfavorable weather change and other environmental impacts had affected the tourism in SNP by disturbing the travel of visitors to move around the area and decrease the length of stay in the past.

Annapurna region is the popular trekking destinations providing the scenic view of Annapurna range, Dhaulagiri, Machapuchhre and many other mountains. There is high diversity of ecosystems ranging from sub-tropical lowlands, temperate forest to the world's highest alpine peaks (Dowling, 2000). To manage the trekking site and biological diversity, conservation area was set up handling management to National Trust for Nature Conservation (NTNC) (Nepal, 1997). Participatory natural resources conservation method was implemented with the full support of local people for making project financially sustainable (Nepal, 1997). To minimize the adverse impacts and strengthen the positive benefits of tourism, bottom up approach based on local management is implemented in Annapurna Conservation Area (ACA) (Dowling, 2000). Inside ACA, visitors can enjoy hiking, mountaineering, viewing wildlife and visiting cultural sites, ethnic museums and natural photography (Baral, et al., 2012). For this, ACAP collect entry fees from international tourist for community development projects on health and sanitation, education, environmental protection, etc. (Nepal, 1997). Unfavorable weather change due to the impact of climate change had caused death of many tourist and had affected trekking around ACA in the past.

Ecotourism in Barpak of Gorkha Nepal was one of the successful rural ecotourism implemented in Nepal. It was able to solve socioeconomic, political, ethnic and gender disparities. There were cleaner pathways, cleaner yards and junctions with shops full of a variety of cleaner products, water taps and public toilets (Acharya \& Halpenny, 2013). The devastating earthquake of April 2015 and its aftershocks had destroyed the Barpak badly as it was the epicenter of the earthquake. Houses which were used as homestays were destroyed and local people are trying to get away from the adverse impacts by focusing on reconstruction of houses.

Total number of tourist arrival in Nepal decreased at the rate of 0.95 percent from 797,616 in 2013 to 790,118 in 2014. Average length of stay had also decreased from 12.51 in 2013 to 12.44 in 2014. Before 2013, annual growth rate of tourist and average length of stay was in increasing trend. Out of total tourist arrival in Nepal, 47.3 percent tourist arrives for the purpose of holiday in 2012 and it increases to 51.5 percent in 2013 (K.C., 2016). The devastating earthquake of April 2015 and its aftershocks had also affected the flow of tourist in Nepal. Many trekking routes in the Langtang, Gaurishankar, Manaslu, Gosainkunda, Rasuwa, Sindupalchowk and Dolakha were affected badly. These area are in reconstruction process and it will take time to recover so that the flow of tourist will increase as that of past. 


\section{Impacts of Ecotourism in Nepal}

As Nepal is rich in ecological, social, cultural and ethnic diversity; there is a great scope of ecotourism for overall development of country. There are positive as well as negative environmental, social and economic impacts of ecotourism.

\section{Environmental Impacts}

Ecotourism helps to enhance forest cover, flora, fauna, greenery, alternative energy sources, natural resource and biodiversity in Ghandruk (K.C., et al., 2015). There are good living rooms, bedrooms, toilets, showers, lodging, clean and comfortable stays, local cuisines, natural scenery and positive interactions with host communities and other benefits to tourist in ACA (Nepal, 2007). There is deforestation, pollution and cultural degradation in Sagarmatha area due to tourism development activities (Musa, et al., 2004). To promote ecotourism; greenery, forest resources, water resources and other natural resources are managed which helps to increase the biodiversity of flora and fauna in the country. But, construction of roads and other infrastructures had decreased the scenic beauty and greenery in the environment disturbing the flow of tourist in the area. Trekking tourism in most of the popular trekking route of Nepal is disturbed by rural road construction.

\section{Social Impacts}

Ecotourism addresses gender inequities, social pride, and excitement of children, peace and prosperity in Barpak. Coordination of local community members, government agency and tourism entrepreneur had helped in the successful implementation of ecotourism project (Acharya \& Halpenny, 2013). Ecotourism had helped in controlling antisocial activities, conserving religious and cultural heritage, maintaining peace and prosperity and increase in cooperation of people with religious beliefs and religious tolerance (K.C., et al., 2015). For the sustainability in SNP, local participation, economic viability, education dissemination, tourist satisfaction, environmental, cultural, economic and social impacts, health and safety of the tourist and minimizing of tourism impact is important (Musa, et al., 2004).

\section{Economic Impacts}

Tourism is one of the important sectors contributing to the economic upliftment of tourism dependent community and one of the small contributors to Nepal's economy. The total foreign exchange earnings and tourism sector contribution to GDP in Nepal in fiscal year 2012/13 was 34,210.6 million and 2.0 percent, respectively (K.C., 2016). It had helped in economic development and job creation to local villagers with the establishment of hotels, restaurants, tea shops, bakery cafes, grocery and gift shops in Ghandruk (K.C., et al., 2015). It is able to generate more income and help local people to provide important basic needs for household consumption in Manaslu 
Conservation Area (K.C. \& Thapa Parajuli, 2014b). It has a great role in poverty alleviation, rural development, agricultural transformation, community enrichment and social empowerment of women in Nepal (Bajracharya, et al., 2011). It has a great role in employment generation and socioeconomic development of a place (K. C., 2016). Growth and development of Pokhara and Annapurna Conservation Area is a good example of economic growth from ecotourism (K. C., 2016). Because of higher incomes, many parents of Manang District of ACA can now afford to send their children to high schools and universities in Kathmandu (Bajracharya, et al., 2011). Challenges of Ecotourism

In the early stage of tourism development, it is difficult to have adequate private agencies and local people involvement in delivering tourism facilities. Lodging, fooding, tour management and tourism activities seems to be unplanned during peak visitation season. There is need of training on nature guiding, cooking and other tourism facilities (Yip, Mohd, Ghani, \& Emby, 2006). It is difficult to get competent and dedicated human capital having good networking skill in ecotourism (Bertella, 2011). Lack of English language communication skills and lack of education is a major challenge for tourism development (Clifton \& Benson, 2006; Schellhorn, 2010).

Climate change is important challenge experienced by local people in different region of Nepal including Manaslu Conservation Area in the form of increase in temperature, irregular rainfall pattern, and less snowfall (K.C. \& Thapa Parajuli, 2014a). There is similar situation felt by local people in Annapurna Conservation Area, Gaurishankar Conservation Area, Sagarmatha region, Kanchenjunga Conservation Area and other trekking routes of Nepal. It is also causing decrease in tourist number and tourist facilities in different region of Nepal.

\section{Needs of Ecotourism}

If the ecotourism concept is to be truly universal, the system must be adaptable and inclusive. Planning and management of ecotourism need to be supervised by a council, advisory board, association and a programme. The roles of the stakeholders involved in the project and hierarchy of the people involved should be clearly articulated as the success of the ecotourism depend on appropriate levels of leadership, cooperation and coordination. A protocol on ecotourism should be developed which covers the standards, appropriate monitoring procedures and criteria. UNESCO World Heritage system and the RAMSAR sites help to guide the formation of the ecotourism system with the centrality of the ecotourism component for achieving sustainability outcomes (Fennell \& Weaver, 2005).

Sustainable use of tourism resources, proper handling of tourism demands, expertise in park management and finance management is important for sustainable development of tourism and tourism management (Eagles, 2002; Shi et al., 2014). 
Biodiversity conservation, cultural heritage preservation, improvement of accessibility, liberalisation of pricing policy, community empowerment, development of tourism facilities, incorporation of nature-based tourism products, interdisciplinary and interdepartmental effort, collaboration between conservation and tourism authorities is necessary to develop ecotourism (Gurung \& Scholz, 2008). Successful ecotourism considers beneficiaries, socioeconomic constraints, impacts on the resource base, inclusion of local benefits, economic viability, education dissemination and tourist satisfaction (Musa, et al., 2004; Tyler \& Dangerfield, 1999).

Support and participation of local communities in tourism planning and development is important for conservation and management to avoid serious conflicts with the management and make ecotourism sustainable (Boxill \& Severin, 2004; Genzong, et al., 2007; Zal \& Breda, 2010). Community involvement, community organizing, environmental education and leadership training is important for sustainable development of ecotourism (Catibog-Sinha \& Wen, 2008).

\section{Conclusions}

Ecotourism helps in biodiversity conservation, poverty reduction and business viability using sustainable principles and practices. Local government officials, local communities, NGOs, private sector and management committee had a great role for tourism development and maintaining healthy cooperation and coordination. It has environmental, social and economic impacts in the community and the whole country. In Nepal, ecotourism helps in environmental conservation, social enhancement and economic development of a particular area where ecotourism is being promoted. It had helped in controlling antisocial activities, conserving religious and cultural heritage, maintaining peace and prosperity and increase in cooperation of people with religious beliefs and religious tolerance. Poverty alleviation, rural development, agricultural transformation and community enrichment is promoted by ecotourism in Nepal. There are many challenges faced by ecotourism entrepreneurs and tourist in the early stage of planning and management. Adequate training on nature guiding, cooking, sustainable use of tourism resources, proper handling of tourism demands, expertise in park management and finance management can help to solve the challenges of ecotourism.

\section{References}

Acharya, B. P., \& Halpenny, E. A. (2013). Homestays as an Alternative Tourism

Product for Sustainable Community Development: A Case Study of Women Managed Tourism Product in Rural Nepal. Tourism Planning \& Development, 10(4), 367-387. doi: 10.1080/21568316.2013.779313

Amati, C. (2013). We all voted for it: Experiences of Participation in Communitybased Ecotourism from the Foothills of Mt Kilimanjaro. Journal of Eastern African Studies, 7(4), 650-670. doi: 10.1080/17531055.2013.841023 
Bajracharya, S. B., Basnet, G., Kharel, F., Shah, K. B., Baral, H. S., \& Charmakar, R. (2011). Gaurishankar Conservation Area: A Treasure House of Himalayan Biodiversity. Lalitpur: National Trust for Nature Conservation, Khumaltar.

Baral, N., Stern, M. J., \& Hammett, A. L. (2012). Developing a Scale for Evaluating Ecotourism by Visitors: A Study in the Annapurna Conservation Area, Nepal. Journal of Sustainable Tourism, 20(7), 975-989. doi: 10.1080/09669582.2012.663379

Bertella, G. (2011). Wildlife Tourism and Natural Sciences Knowledge: Challenges and Critical Factors. Scandinavian Journal of Hospitality and Tourism, 11(1), 97 114. doi: 10.1080/15022250.2011.540794

Bhusal, N. P. (2007). Chitwan National Park: A Prime Destination of Eco-Tourism in Central Tarai Region, Nepal. The Third Pole, 5(7), 70-75.

Bin, L., Suocheng, D., \& Mei, X. (2008). Ecotourism Model and Benefits of Periphery Regions in Western Sichuan Province. Chinese Journal of Population Resources and Environment, 6(2), 80-86. doi: 10.1080/10042857.2008.10684873

Boxill, I., \& Severin, F. O. (2004). An Exploratory Study of Tourism Development and Its Impact on the Caribs of Dominica. International Journal of Hospitality \& Tourism Administration, 5(1), 1-27. doi: 10.1300/J149v05n01_01

Brunet, S., Bauer, J., De Lacy, T., \& Tshering, K. (2001). Tourism Development in Bhutan: Tensions between Tradition and Modernity. Journal of Sustainable Tourism, 9(3), 243-263. doi: 10.1080/09669580108667401

Burakowski, E., \& Magnusson, M. (2012). Climate Impacts on the Winter Tourism Economy in the United States. In A. Kennaugh (Ed.): University of New Hampshire.

Catibog-Sinha, C., \& Wen, J. (2008). Sustainable Tourism Planning and Management Model for Protected Natural Areas: Xishuangbanna Biosphere Reserve, South China Asia Pacific Journal of Tourism Research, 13(2), 145-162. doi: $10.1080 / 10941660802048431$

CBS. (2014). ENVIRONMENT STATISTICS OF NEPAL 2013. Kathmandu: Government of Nepal National Planning Commission Secretariat Central Bureau of Statistics.

Ceballos-Lascurain, H. (1996). Tourism, Ecotourism and Protected Areas: The State of Nature-based Tourism Around the World and Guidelines for its Development. Gland, Switzerland: IUCN.

Chan, J. K. L., \& Baum, T. (2007). Ecotourists' Perception of Ecotourism Experience in Lower Kinabatangan, Sabah, Malaysia. Journal of Sustainable Tourism, 15(5), 574-590. doi: 10.2167/jost679.0 
Clifton, J., \& Benson, A. (2006). Planning for Sustainable Ecotourism: The Case for Research Ecotourism in Developing Country Destinations. Journal of Sustainable Tourism, 14(3), 238-254. doi: 10.1080/09669580608669057

Cusack, D., \& Dixon, L. (2006). Commimity-Based Ecotourism and Sustainability. Journal of Sustainable Forestry, 22(1-2), 157-182. doi: 10.1300/J091v22n01_09

Das, N., \& Syiemlieh, H. J. (2009). Ecotourism in Wetland Ecology. Anatolia: An International Journal of Tourism and Hospitality Research, 20(2), 445-450. doi: 10.1080/13032917.2009.10518920

Degang, W., \& Xiaoting, H. (2006). Coincidence and Upgrade: A Typical Case Study of Rural Ecotourism Development. Chinese Journal of Population Resources and Environment, 4(1), 45-53. doi: 10.1080/10042857.2006.10677449

Doan, T. M. (2000). The Effects of Ecotourism in Developing Nations: An Analysis of Case Studies. Journal of Sustainable Tourism, 8(4), 288-304. doi: $10.1080 / 09669580008667365$

Dowling, R. K. (2000). Global Ecotourism at the Start of the New Millennium. World Leisure Journal, 42(2), 11-19. doi: 10.1080/04419057.2000.9674182

Duffy, R. (2008). Neoliberalising Nature: Global Networks and Ecotourism Development in Madagasgar. Journal of Sustainable Tourism, 16(3), 327-344. doi: 10.1080/09669580802154124

Eagles, P. F. J. (2002). Trends in Park Tourism: Economics, Finance and Management. Journal of Sustainable Tourism, 10(2), 132-153. doi: 10.1080/09669580208667158

Fennell, D., \& Weaver, D. (2005). The Ecotourium Concept and TourismConservation Symbiosis. Journal of Sustainable Tourism, 13(4), 373-390. doi: 10.1080/09669580508668563

Genzong, X., Penghua, Q., \& Shaoxia, T. (2007). Nature Reserve and Ecotourism DevelopmentinChina'sWuzhishanMountain Region.Chinese JournalofPopulation Resources and Environment, 5(1), 74-83. doi: 10.1080/10042857.2007.10677491

Gezon, L. L. (2014). Who Wins and Who Loses? Unpacking the Local People Concept in Ecotourism: A Longitudinal Study of Community Equity in Ankarana, Madagascar. Journal of Sustainable Tourism, 22(5), 821-838. doi: 10.1080/09669582.2013.847942

Gurung, D. B., \& Scholz, R. W. (2008). Community-based Ecotourism in Bhutan: Expert Evaluation of Stakeholder-based Scenarios. International Journal of Sustainable Development \& World Ecology, 15(5), 397-411. doi: 10.3843/ SusDev.15.5:1 
Hawkins, D. E. (2004). A Protected Areas Ecotourism Competitive Cluster Approach to Catalyse Biodiversity Conservation and Economic Growth in Bulgaria. Journal of Sustainable Tourism, 12(3), 219-244. doi: 10.1080/09669580408667235

Honey, M. (2008). Ecotourism and Sustainable Development: Who Owns Paradise? (Second Edition ed.). Washington D.C., USA: Island Press.

K. C., A. (2016). Ecotourism and Its Role in Sustainable Development of Nepal. In L. Butowski (Ed.), Tourism - From Empirical Research Towards Practical Application (pp. 31-59): In Tech.

K.C., A. (2016). Hydropower Development, Ecotourism and Green Economy in the Context of Nepal. Bidhyut, 26(2), 9-13.

K.C., A., Rijal, K., \& Sapkota, R. P. (2015). Role of ecotourism in environmental conservation and socioeconomic development in Annapurna conservation area, Nepal. International Journal of Sustainable Development \& World Ecology, 22(3), 251-258. doi: 10.1080/13504509.2015.1005721

K.C., A., \& Thapa Parajuli, R. B. (2014a). Climate Change and Its Impact on Tourism in the Manaslu Conservation Area, Nepal. Tourism Planning \& Development, 13. doi: 10.1080/21568316.2014.933122

K.C., A., \& Thapa Parajuli, R. B. (2014b). Tourism and Its Impact on Livelihood in Manaslu Conservation Area, Nepal. Environment Development and Sustainability, 16, 1053-1063. doi: 10.1007/s10668-013-9512-7

Kelkit, A., Ozel, A. E., \& Demirel, O. (2005). A Study of the Kazdagi (Mt. Ida) National Park: An Ecological Approach to the Management of Tourism. International Journal of Sustainable Development \& World Ecology, 12(2), 141-148. doi: $10.1080 / 13504500509469625$

Kontogeorgopoulos, N. (2005). Community-Based Ecotourism in Phuket and Ao Phangnga, Thailand:nPartial Victories and Bittersweet Remedies. Journal of Sustainable Tourism, 13(1), 4-23. doi: 10.1080/17501220508668470

Lieberknecht, K., \& Papazian, J. (1999). Balancing Conservation and Economics, The Development of an Ecotourism Plan for Panama. Journal of Sustainable Forestry, 8(3-4), 107-126. doi: 10.1300/J091v08n03_09

Maikhuri, R. K., Rana, U., Rao, K. S., Nautiyal, S., \& Saxena, K. G. (2000). Promoting Ecotourism in the Buffer Zone Areas of Nanda Devi Biosphere Reserve: An Option to Resolve People-policy Conflict. International Journal of Sustainable Development \& World Ecology, 7(4), 333-342. doi: 10.1080/13504500009470052

Musa, G., Hall, C. M., \& Higham, J. E. S. (2004). Tourism Sustainability and Health Impacts in High Altitude Adventure, Cultural and Ecotourism Destinations: A 
Case Study of Nepal's Sagarmatha National Park. Journal of Sustainable Tourism, 12(4), 306-331. doi: 10.1080/09669580408667240

Nath, T. K., \& Alauddin. (2006). Sitakunda Botanical Garden and Eco-park, Chittagong, Bangladesh: Its Impacts on a Rural Community. International Journal of Biodiversity Science \& Management, 2(1), 1-11.doi: 10.1080/17451590609618095

Nepal, S. K. (1997). Sustainable Tourism, Protected Areas and Livelihood Needs of Local Communities in Developing Countries. International Journal of Sustainable Development \& World Ecology, 4(2), 123-135. doi: 10.1080/13504509709469948

Nepal, S. K. (2007). Ecotourists' Importance and Satisfaction Ratings of Accommodation-Related Amenities. Anatolia: An International Journal of Tourism and Hospitality Research, 18(2), 255-276. doi: 10.1080/13032917.2007.9687205

Ormsby, A., \& Mannle, K. (2006). Ecotourism Benefits and the Role of Local Guides at Masoala National Park, Madagascar. Journal of Sustainable Tourism, 14(3), 271-287. doi: 10.1080/09669580608669059

Randall, A. (1987). Resource Economics (Second Edition ed.). New York, USA: John Wiley and Sons.

Schellhorn, M. (2010). Development for Whom? Social Justice and the Business of Ecotourism. Journal of Sustainable Tourism, 18(1), 115-135. doi: 10.1080/09669580903367229

Shi, L., Zhao, H., Li, Y., Ma, H., Yang, S., \& Wang, H. (2014). Evaluation of Shangri-La County's tourism resources and ecotourism carrying capacity. International Journal of Sustainable Development \& World Ecology. doi: 10.1080/13504509.2014.927018

Sindiga, I. (1999). Alternative Tourism and Sustainable Development in Kenya. Journal of Sustainable Tourism, 7(2), 108-127. doi: 10.1080/09669589908667330

Singh, T. V., \& Singh, S. (2004). On Bringing People and Park Together through Ecotourism: The Nanda Devi National Park, India. Asia Pacific Journal of Tourism Research, 9(1), 43-55. doi: 10.1080/1094166042000199602

Sreekumar, T. T., \& Parayil, G. (2002). Contentions and Contradictions of Tourism as Development Option: The Case of Kerala, India. Third World Quarterly, 23(3), 529-548. doi: 10.1080/01436590220138411

Stem, C. J., Lassoie, J. P., Lee, D. R., \& Deshler, D. J. (2003). How Eco is Ecotourism? A Comparative Case Study of Ecotourism in Costa Rica. Journal of Sustainable Tourism, 11(4), 322-347. doi: 10.1080/09669580308667210

Sung, T. P., Bagul, H. B. P., Sentian, J., \& Dambul, R. (2012). Developing and Promoting a Highland Community Livelihood for Sustainable Tourism: The Case of Kg. Bundutuhan, Ranau, Sabah. Malaysia Journal of Society and Space, 8(5), 94 - 99. 
TIES. (1990). What is Ecotourism? Retrieved May 14, 2014, from https://www. ecotourism.org/what-is-ecotourism

Tyler, D., \& Dangerfield, J. M. (1999). Ecosystem Tourism: A Resource-based Philosophy for Ecotourism. Journal of Sustainable Tourism 7(2), 146-158. doi: $10.1080 / 09669589908667332$

UNEP. (2013). Tourism: Trends, Challenges and Opportunities Green Economy and Trade (pp. 259-291): United Nations Environment Programme.

Winson, A. (2006). Ecotourism and Sustainability in Cuba: Does Socialism Make a Difference? Journal of Sustainable Tourism, 14(1), 6-23. doi: $10.1080 / 09669580608668588$

Wood, M. A. (2002). Ecotourism: Principles, Practices and Policies for Sustainability (First ed.). Paris, France: United Nation Publication.

Yip, H.W., Mohd,A., Ghani, A.N. A., \&Emby,Z.(2006).ParticipatoryofLocalOperators in Ecotourism Services Delivery: The Nature-based Tourism Development in Pahang National Park, Malaysia. Anatolia: An International Journal of Tourism and Hospitality Research, 17(2), 313-318. doi: 10.1080/13032917.2006.9687192

Zal, N., \& Breda, Z. (2010). Tourism in Protected Areas: Observations from Kuscenneti National Park. Anatolia: An International Journal of Tourism and Hospitality Research, 21(1), 73-87. doi: 10.1080/13032917.2010.9687091

Zambrano, A. M. A., Broadbent, E. N., \& Durham, W. H. (2010). Social and Environmental Effects of Ecotourism in the Osa Peninsula of Costa Rica: The Lapa Rios Case. Journal of Ecotourism, 9(1), 62-83. doi: 10.1080/14724040902953076 